\title{
Genetic divergence among Dimorphandra spp. accessions using RAPD markers
}

\author{
Divergência genética entre acessos de Dimorphandra spp. usando marcadores RAPD
}

\author{
Cláudia Pombo Sudré ${ }^{\mathrm{I}}$ Rosana Rodrigues ${ }^{\mathrm{I}}$ Leandro Simões Azeredo Gonçalves $^{\mathrm{I}}$ \\ Ernane Ronie Martins ${ }^{\mathrm{II}}$ Messias Gonzaga Pereira ${ }^{\mathrm{I}}$ Marilene Hilma dos Santos $^{\mathrm{I}}$
}

\begin{abstract}
The genus Dimorphandra has distinguish relevance considering either medicinal or biodiversity aspects because it includes two species that are economically important flavonoids sources for pharmachemical industry (D. mollis Benth. and D. gardneriana Tul.), and species endemic to Brazil, such as D. jorgei Silva and D. wilsonii Rizz., threatened by extinction. In order to evaluate variability among accessions of D. mollis (fava-d'anta), D. gardneriana and D. wilsonii, it was collected fruit from individual plants from three Brazilian states in a total of 57 accessions, which were analyzed with RAPD markers. It was used 20 seeds per progeny; the DNA was extracted from fully-formed young leaves, which were collected in bulk. The data were analyzed using a binary matrix, in which the score one represented presence of a band and zero, absence. The similarity matrix was developed by using the arithmetic complement of the Jaccard index, later grouped based on the Neighbor Joining algorithm. It was found considerable intra and inter specific variability in Dimorphandra spp., which were separated into four groups. Though genetic variability was found, the collecting trips showed that most of these areas are subject to loss of genetic resources of fava-d'anta due to the following factors: continuous anthropic activity, propensity for natural fires, and loss of natural seed dispersers (large fruit-eating mammals). Therefore, protections of these areas and ex situ conservation are essentials for the maintenance of genetic variability of these species.
\end{abstract}

Key words: fava-d'ant, molecular characterization, plant genetic resource, germoplasm.

\section{RESUMO}

O gênero Dimorphandra tem grande relevância, sobretudo nos aspectos medicinais e de biodiversidade, por incluir duas espécies que são importantes economicamente como fontes de flavonoides para indústria farmacoquímica (D. mollis Benth. e D. gardneriana Tull.), e espécies endêmicas do Brasil, como a D. jorgei Silva e D. wilsonii Rizz., sendo esta ameaçada de extinção. Objetivando avaliar a variabilidade entre acessos de D. mollis, D. gardneriana e D. wilsonii, foram realizadas coletas de frutos separados por planta em três estados brasileiros em um total de 57 acessos que foram analisados por meio da técnica RAPD. Utilizaram-se vinte sementes por progênie e o DNA, extraído de folhas definitivas, jovens, $e$ coletadas em bulk. Os dados foram analisados utilizando-se uma matriz de dados binários. Para formação da matriz de dissimilaridade, foi utilizado o complemento aritmético do Índice de Jaccard e posteriormente o agrupamento pelo algoritmo de Neighbor Joining. O estudo revelou que existe variabilidade entre e dentro das espécies de Dimorphandra spp., o qual formou quatro grupos. Apesar da variabilidade genética constatada, as expedições de coleta demonstraram que a maioria das áreas amostradas está sujeita a perdas de recursos genéticos de fava-d'anta devido aos seguintes fatores: ocorrência de ação antrópica contínua; propensão a incêndios naturais; e diminuição dos dispersores naturais de sementes (grandes mamíferos frugiveros). Assim, a proteção destas áreas e a conservação ex situ, são primordiais para manutenção da variabilidade genética dessas espécies.

Palavras-chave: fava-d'anta, caracterização molecular, recursos genéticos vegetais, germoplasma.

\section{INTRODUCTION}

The market for medicinal plants increases about $10 \%$ each year and only for phytoterapics is expected an annual movement of US\$ 20 billions

'Universidade Estadual do Norte Fluminense Darcy Ribeiro (UENF), 28013-602, Campos dos Goytacazes, RJ, Brasil. E-mail: cpombo@uenf.br. *Autor para correspondência.

"Universidade Federal de Minas Gerais (UFMG), Montes Claros, MG, Brasil. 
worldwide. In Brazil, the value of this market is estimated in about US\$ 400 millions with potential to reach US\$ 2 trillion only using Brazilian native plants (RAMOS, 2010). Demand for native medicinal plants in Brazil tends to increase with the discovery of substances that still cannot be produced synthetically. This is the case for fava-d'anta (Dimorphandra spp.), which fruits have considerable concentrations of flavonoids, especially rutin and quercetin. According to HUBINGER et al. (2009), content of flavonoids can reach about $10.25 \%$ in dried ground fruit. These are among the most commonly exported pharmacological products produced in Brazil, accounting for $50 \%$ of world production. In 2008, the Brazilian exports of rutin and quercetin summed US\$ 6.2 million and US\$ 2.6 million respectively (abiquifi.org.br).

This genus occurs mainly in cerrado (savannah-like), ecosystem from several Brazilan states, such as Amazonas, Bahia, São Paulo, Maranhão, Pará, Piauí, Ceará, Tocantins, Pernambuco, Minas Gerais, Goiás, Mato Grosso and Mato Grosso do Sul. The number of known species varies from 11 to 43 in the genus Dimorphandra (GONÇALVES, 2007; INPI, 2009). Among these, the D. mollis Benth. and $\boldsymbol{D}$. gardneriana Tul. are considered the most important because they are most frequently found in nature, being the most collected and used in chemical and pharmaceutical industry (GONÇALVES et al., 2010; CUNHA et al., 2009). Nevertheless, D. wilsonii Rizz. is also considered potentially important because the fruit size as much when compared with the other two species, producing at least three times more rutin (FERNANDES et al., 2007).

Due to the threat of extinction, there is concern about surviving and maintaining the species D. mollis and D. gardneriana, since they are used commercially only through extractivism. An analysis to study the genetic erosion risk was made on 32 populations of $\boldsymbol{D}$. mollis Benth. in northern Minas Gerais state indicated that $41 \%$ of the populations had risk of genetic erosion of $40 \%$ or above. The main risk factors that contributed most were extractive harvesting, lack of protection of local habitats and forest fires (SOUZA \& MARTINS, 2004).

D. wilsonii, an endemic species of Minas Gerais state, is on the Red List of Threatened Plants of the IUCN (International Union for Conservation of Nature and Natural Resources) in the category "critically endangered" and currently fewer than 50 mature plants are found in nature, located on private properties in the cities of Paraopeba, Pequi, Lagoa Santa and Sete Lagoas, all in the state of Minas Gerais (SOUZA et al., 2009).

In order to take proper measures to help the Dimorphandra spp. germplasm conservation, it is necessary to have information on the genetic structure of the populations, as well as variability between populations. One of the tools used for this purpose is molecular markers, which allow inferences on genetic diversity among and within populations (SCHLÖTTERER, 2004; SCHULMAN, 2007; HUANG et al., 2009).

In studies of plant conservation, the Random Amplified Polymorphic DNA (RAPD) is one of the techniques indicated for species for which there is little genetic information and that are rare or threatened by extinction, since it uses short random sequence primers, requires little material for analysis and is relatively fast (LYNCH \& MILLIGAN, 1994; LACERDA et al., 2002). Genetic variability was examined among accessions of D. mollis, D. gardneriana and $D$. wilsonii, from several Brazilian localities using RAPD markers.

\section{MATERIAL AND METHODS}

Obtaining vegetal material

Fruits of the species D. mollis Benth. (favad'anta), D. gardneriana Tul. and $\boldsymbol{D}$. wilsonii Rizz. were collected in 57 accessions from 19 localities of three Brazilian states: Minas Gerais, Maranhão and Tocantins (Table 1). Areas with elevated anthropic influence were included, mainly due to extractive harvesting of favad'anta fruit, along with areas within a conservation unit, named Lajeado State Park, Tocantins state.

Fruit from one to ten plants of each accession were collected, generally from five plants, depending on the availability at the time they were harvested. Twenty seeds were collected from each plant to produce seedlings. The seeds were removed, mechanically scarified with the help of a carborundum stone and planted in containers filled with organic substrate, maintained in a greenhouse. As a divergent standard, Cassia grandis L.f. that belongs to the same subfamily as the genus Dimorphandra, was included for the analysis.

Young leaves were collected from 57 accessions and from the $\boldsymbol{C}$. grandis L.f. accession. After harvesting, the leaves were taken to the laboratory and macerated. Part of the macerated material was frozen in liquid $\mathrm{N}_{2}$ and placed in $15 \mathrm{~mL}$ tubes, capped, labeled, and maintained at $-86^{\circ} \mathrm{C}$. Another part of the material was used to extract DNA.

\section{Isolation of genomic DNA}

Genomic DNA was extracted using the CTAB method (DOYLE \& DOYLE, 1990), modified by DAHER et al. (2002). DNA was quantified in $0.8 \%$ agarose gel using the High DNA Mass Ladder (Invitrogen ${ }^{\circledR}$, USA). Samples were stained with a mixture 
Table 1 - Geographic references of the Dimorphandra spp accessions collected in Brazilian States.

\begin{tabular}{|c|c|c|c|c|c|c|}
\hline City & $\begin{array}{c}\text { Accession } \\
\text { number }\end{array}$ & Region/State & Latitude & Longitude & Altitude (m) & Species \\
\hline Bocaiúva & 01 & North/MG ${ }^{1 /}$ & $\mathrm{S} 17^{\circ} 10^{\prime}$ & W43눈 & 799 & D. mollis Benth. \\
\hline Brasília de Minas & 08 & North/MG & $\mathrm{S} 16^{\circ} 10^{\prime}$ & W44 $24^{\circ}$ & 810 & D. mollis Benth. \\
\hline Montes Claros & 05 & North/MG & $\mathrm{S} 16^{\circ} 25^{\prime}$ & $\mathrm{W} 44^{\circ} 02^{\prime}$ & 845 & D. mollis Benth. \\
\hline Coração de Jesus & 05 & North/MG & $\mathrm{S} 16^{\circ} 51^{\prime}$ & W44 $04^{\circ}$ & 738 & D. mollis Benth. \\
\hline Barra do Corda & 05 & Central/MA & $\mathrm{S} 05^{\circ} 30^{\prime}$ & W45 $14^{\prime}$ & 83 & D. gardneriana Tul. \\
\hline Barra do Corda & 05 & Central/MA & $\mathrm{S} 05^{\circ} 30^{\prime}$ & $\mathrm{W} 45^{\circ} 14^{\prime}$ & 83 & D. gardneriana Tul. \\
\hline Paraopeba & 02 & Metropolitana/MG & $\mathrm{S} 19^{\circ} 16^{\prime}$ & $\mathrm{W} 44^{\circ} 24^{\prime}$ & 733 & D. wilsonii Rizz. \\
\hline Japonvar & 02 & North/MG & $\mathrm{S} 16^{\circ} 02^{\prime}$ & W $44^{\circ} 14^{\prime}$ & 798 & D. mollis Benth. \\
\hline Jequitaí & 02 & North/MG & $\mathrm{S} 17^{\circ} 13^{\prime}$ & W44 $29^{\prime}$ & 559 & D. mollis Benth. \\
\hline Chapadinha & 01 & Northeast/MA & $\mathrm{S} 03^{\circ} 44^{\prime}$ & $\mathrm{W} 43^{\circ} 21^{\prime}$ & 105 & D. gardneriana Tul. \\
\hline Mirabela & 02 & North/MG & $\mathrm{S} 16^{\circ} 16^{\prime}$ & $\mathrm{W} 44^{\circ} 09^{\prime}$ & 792 & D. mollis Benth. \\
\hline Olhos d'Água & 03 & North/MG & $\mathrm{S} 17^{\circ} 26^{\prime}$ & W43 $37^{\prime}$ & 780 & D. mollis Benth. \\
\hline Patrocínio & 01 & Alto do Parnaíba/MG & $\mathrm{S} 18^{\circ} 56^{\prime}$ & W46 $59^{\prime}$ & 965 & D. mollis Benth. \\
\hline Pirapora & 01 & North/MG & $\mathrm{S} 17^{\circ} 20^{\prime}$ & W $44^{\circ} 56^{\prime}$ & 489 & D. mollis Benth. \\
\hline Claro dos Poções & 07 & North/MG & S $16^{\circ} 57^{\prime}$ & $\mathrm{W} 44^{\circ} 16^{\prime}$ & 730 & D. mollis Benth. \\
\hline Palmas & 02 & TO & $\mathrm{S} 10^{\circ} 00^{\prime}$ & $\mathrm{W} 48^{\circ} 15^{\prime}$ & 625 & Dimorphandra sp. \\
\hline Palmas & 03 & TO & $\mathrm{S} 10^{\circ} 00^{\prime}$ & $\mathrm{W} 48^{\circ} 15^{\prime}$ & 625 & Dimorphandra sp. \\
\hline Palmas & 01 & TO & $\mathrm{S} 10^{\circ} 00^{\prime}$ & $\mathrm{W} 48^{\circ} 15^{\prime}$ & 625 & Dimorphandra sp. \\
\hline Uberlândia & 01 & Triângulo Mineiro/MG & $\mathrm{S} 18^{\circ} 55^{\prime}$ & $\mathrm{W} 48^{\circ} 16^{\prime}$ & 863 & D. gardneriana Tul. \\
\hline
\end{tabular}

${ }^{1 /} \mathrm{MG}=$ Minas Gerais State; MA = Maranhão State $; \mathrm{TO}=$ Tocantins State.

of Blue Juice with Gel Red (1:1) to visualize the bands in the gel and the image recorded using MiniBis Pro.

RAPD analysis

Sixteen RAPD primers randomly chosen were tested, because there was no information available about polymorphic primers for Dimorphandra spp. considering this a molecular marker (Table 2). The amplification reactions were run in a Mastercycler gradient (Eppendorf) thermocycler in a final volume of $15 \mu \mathrm{L}$, containing 10ng of DNA, $10 \mathrm{mmol} \mathrm{L}^{-1}$ Tris $\mathrm{HCl}$ (pH8.3), $50 \mathrm{mmol} \mathrm{L}^{-1} \mathrm{KCl}, 2.0 \mathrm{mmol} \mathrm{L}^{-1} \mathrm{MgCl}_{2}, 100 \mathrm{mM}$ of dNTP, $0.4 \mathrm{mM}$ of primer, and $0.75 \mathrm{U}$ of Taq DNA polymerase. The reaction mixture was submitted to 45 amplification cycles after an initial denaturation step at $95^{\circ} \mathrm{C}$ for $1 \mathrm{~min}$. Each cycle consisted of $1 \mathrm{~min}$ at $94^{\circ} \mathrm{C}$, $1 \mathrm{~min}$ at $36^{\circ} \mathrm{C}$ and $2 \mathrm{~min}$ at $72^{\circ} \mathrm{C}$. There was a final extension step at $72^{\circ} \mathrm{C}$ for $7 \mathrm{~min}$. The amplification products were submitted to electrophoresis in $1.4 \%$ agarose gels. The bands were visualized by staining with a mixture of Blue Juice with Gel Red (1:1) and the images recorded with MiniBis Pro.

Data analysis

The data were obtained by visual evaluation of the strongest and most consistent bands. A binary matrix was prepared, with 1 and 0 corresponding to presence and absence of the band, respectively. A similarity matrix was constructed using the arithmetic complement of the Jaccard index, and then clustered by Neighbor Joining (SAITOU \& NEI, 1987). All of the analyses were done using the program DARwin 5 (PERRIER et al., 2003).

\section{RESULTS AND DISCUSSION}

According to the RAPD analysis, each primer produced easily detected bands of variable intensity, and nonspecific bands, which were discarded. The 16 primers used produced 100 bands (Table 2). Out of these, 96 were polymorphic and four monomorphic. The number of polymorphic bands per primer varied from one to 11 , with a mean of six bands per primer. The degree of polymorphism for each primer varied from 60 to $100 \%$ (Table 2), with a mean of $96 \%$.

The dendrogram obtained using Neighbor Joining algorithm allowed us to separate the accessions into five distinct groups (Figure 1). Accessions 58 and 35,40 and 47 were the most distant from the others; accession 58 was of the species $\boldsymbol{C}$. grandis L.f. Although the accessions 35, 40 and 47 had formed a separate cluster, seeds from these accessions were collected in Tocantins state and they were originally identified as Dimorphandra sp. based on phenotypic 
Table 2 - Number of polymorphic and monomorphic bands obtained with RAPD markers in 57 accessions from 19 Brazilian localities of Dimorphandra spp. using 16 primers.

\begin{tabular}{llccc}
\hline Primer & Sequence 5,3, & Polymorphic bands & Monomorphic bands & $\%$ of polymorphism \\
\hline OPAA11 & ACCCGACCTG & 8 & 1 & 89 \\
OPA12 & TCGGCGATAG & 8 & 0 & 100 \\
OPAA16 & GGAACCCACA & 6 & 0 & 100 \\
OPAA18 & TGGTCCAGCC & 4 & 0 & 100 \\
OPAA19 & TGAGGCGTGT & 9 & 0 & 100 \\
OPAE06 & GGGGAAGACA & 6 & 0 & 100 \\
OPAE07 & GTGTCAGTGG & 11 & 0 & 100 \\
OPAE09 & TGCCACGAGG & 1 & 0 & 100 \\
OPAE08 & CTGGCTCAGA & 3 & 0 & 100 \\
OPAE15 & TGCCTGGACC & 4 & 0 & 60 \\
OPAE18 & CTGGTGCTGA & 3 & 2 & 87.5 \\
OPAE20 & TTGACCCCAG & 7 & 1 & 100 \\
OPAW09 & ACTGGGTCGG & 6 & 0 & 100 \\
OPBO7 & GGTGACGCAG & 10 & 0 & 100 \\
OPB19 & ACCCCCGAAG & 6 & 0 & 100 \\
OPD19 & CTGGGGACTT & 4 & 0 & 4 \\
Total & 16 & 96 & 4 & \\
\hline
\end{tabular}

traits. However, it was not possible to cluster these three accessions together with other Dimorphandra representatives only using RAPD markers. It can be seen that these accessions are distant from accessions of $\boldsymbol{D}$. mollis Benth., D. gardneriana Tul. and D. wilsonii Rizz., leading to suppose that they are of a different species. The International Plant Names Index has 43 species of this genus registered, so that confusion in species recognition is possible.

The accessions of $\boldsymbol{D}$. mollis had a mean intragroup distance, based on the Jaccard coefficient, of $0.2304( \pm 0.08)$; which were allocated to the same group based on the Neighbor Joining algorithm. The same was found for accessions of D. gardneriana Tul., though with a mean intragroup distance of 0.3738 $( \pm 0.09)$. The species $\boldsymbol{D}$. mollis was collected from 13 localities in Minas Gerais, Brazil, covering three mesoregions in this state, with a maximum distance of $600 \mathrm{~km}$ between collection sites. On the other hand, $\boldsymbol{D}$. gardneriana was collected from fewer localities of Maranhão and Minas Gerais states. Also, two accessions of $\boldsymbol{D}$. gardneriana collected in Barra do Corda, Maranhão, came from different management regimes, one in a cultivated area and the other in a region where it occurs naturally. Accession 29 (Uberlândia, Minas Gerais) presented the greatest genetic distance from other D. gardneriana accessions; geographically, it is $2000 \mathrm{~km}$ from the collection localities in Maranhão. There are few records of D. gardneriana in Minas Gerais and then, investigations in this state could be useful to prospect genetic variation for breeding programs.

Two accessions of $\boldsymbol{D}$. wilsonii, from Paraopeba, Minas Gerais, had a genetic distance of 0.3594; they were in the same cluster based on Neighbor Joining. In 2007, when these two accessions were collected, only 11 plants were recorded, all of them outside protected areas, in locations impacted by anthropization (FERNANDES et al., 2007). Nevertheless, it can be seen that there is variability between these genotypes.

The results obtained demonstrate the serviceable of RAPD markers for studying genetic diversity among Dimorphandra spp. accessions. The usefulness of this type of marker in allogamous plants was demonstrated by PAMIDIAMARRI et al. (2009), who evaluated interspecific genetic diversity with RAPD and AFLP markers, among Jatropha accessions and concluded that both types of markers were concordant and that they can be used to identify interspecific hybrids, for marker-assisted selection and for managing genetic resources. LEAL et al. (2010), comparing RAPD and microsatellites markers for studying popcorn lines, an allogamous plant, as is favad'anta, concluded that both techniques provide consistent information and can be used to study genetic diversity in popcorn.

Data obtained by OLIVEIRA et al. (2008), using RAPD markers in a study of 44 genotypes of $\boldsymbol{D}$. mollis Benth. from six localities in northern Minas 


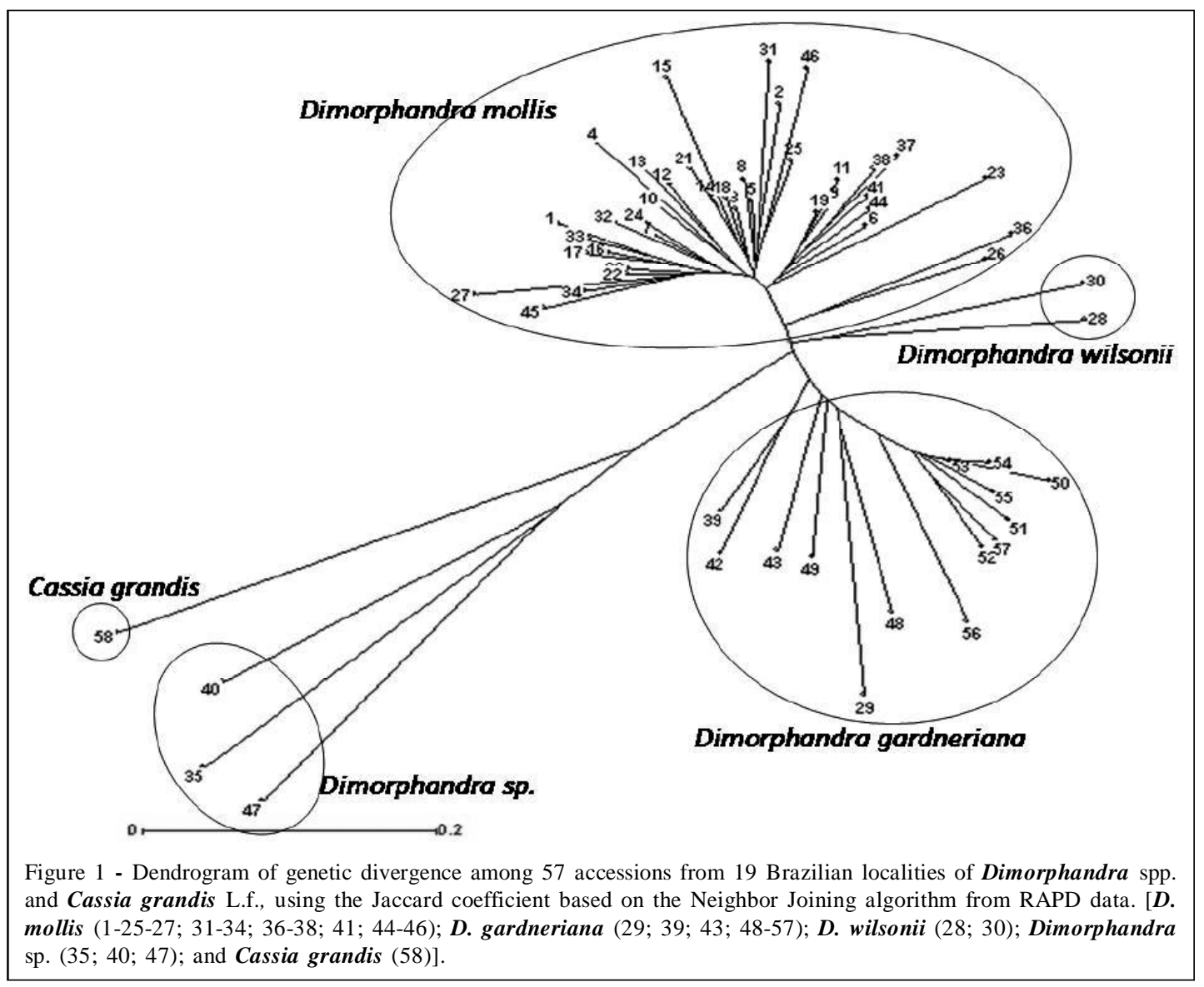

Gerais, demonstrated that the populations were constituted by closely-related genotypes, since they found a low degree of polymorphism. The maximum distance between the collection locations was $270 \mathrm{~km}$.

The genotypes that were analyzed in this study came from areas up to $2000 \mathrm{~km}$ apart, allowing us to find diverse genotypes with potential for use in breeding programs. Consequently, though most of the areas from which collections were made, are under continuous anthropic influence, besides being prone to fires and reduced seed distribution, the last due to a decrease in natural seed dispersers (large fruit eating mammals), there is still considerable genetic diversity between and within species of Dimorphandra spp. Therefore, prospection in new areas, protection in areas which already have been studied and ex situ protection is primordial for the maintenance of genetic variability in these species.

\section{CONCLUSION}

There is genetic variability among and within species Dimorphandra spp. using RAPD markers. Three accessions (35, 40 and 47) need further investigations to cluster them in the genus Dimorphandra.

\section{REFERENCES}

ABIQUIF. Associação Brasileira da Indústria Farmoquímica. Campos dos Goytacazes, 09 de abr. 2009. Available from: <http://www.abiquif.org.br>. On line. Accessed: 02 de jan. 2010.

CUNHA, P.L.R. et al. Isolation and characterization of galactomannan from Dimorphandra gardneriana Tul. seeds as a potential guar gum substitute. Food Hydrocolloids, v.23, p.880-885, 2009. Available from: <http://dx.doi.org/10.1016/ j.foodhyd.2008.05.005>. Accessed: Jan. 23, 2011. doi: 10.1016/j.foodhyd.2008.05.005.

DAHER, R.F. et al. Genetic divergence among elephantgrass cultivars assessed by RAPD markers in composit samples. Scientia Agricola, v.59, p.623-627, 2002. Available from: <http:// dx.doi.org/10.1590/S0103-90162002000400001>. Accessed: Jan. 24, 2011. doi: 10.1590/S0103-90162002000400001.

DOYLE, J.J.; DOYLE, J.L. Isolation of plant DNA from fresh tissue. Focus, v.12, p.13-15, 1990.

FERNANDES, F.M. et al. Tentando evitar mais uma extinção: o caso do "Faveiro de Wilson" (Dimorphandra wilsonii Rizzini). 
In: PEREIRA, T.S. et al. (Org.). Recuperando o verde para as cidades: a experiência dos jardins botânicos brasileiros. Rio de Janeiro: Rede Brasileiro de Jardins Botânicos; Instituto de Pesquisas Jardim Botânico do Rio de Janeiro; BGCI, 2007. p.87-98.

GONÇALVES, A.C. Estrutura genética em populações naturais de Dimorphandra mollis Benth. (Fabaceae). 2007. 83f. Dissertação (Mestrado em Engenharia Florestal) - Curso de Pós-graduação em Engenharia Florestal, Universidade Federal de Lavras, MG

GONÇALVES, A.C. et al. Estrutura genética espacial em populações naturais de Dimorphandra mollis (Fabaceae) na região Norte de Minas Gerais, Brasil. Revista Brasileira de Botânica, v.33, p.325-332, 2010. Available from: <http:// dx.doi.org/10.1590/S0100-67622010000100011>. Accessed: Jan. 23, 2011. doi: 10.1590/S0100-67622010000100011.

HUBINGER, S. et al. Controles físico-químico, químico e microbiológico dos frutos de Dimorphandra mollis Benth., Fabaceae. Revista Brasileira de Farmacognosia, v.19, p.690-696, 2009. Available from: <http://www.scielo.br/ scielo.php? script=sci_arttext \& pid=S 0102 695X2009000500007\&lng=en\&nrm=iso>. Accessed: Jan. 22, 2011. doi: $10.1590 / \mathrm{S} 0102-695 \times 2009000500007$

HUANG, Y. et al. Genetic diversity and genetic structure analysis of the natural populations of Lilium brownii from Guangdong, China. Biochemical Genetics, v.47, p.503-510, 2009. Available from: 〈http://dx.doi.org/10.1007/s10528-009-9258-y>. Accessed: Jan. 23, 2011. doi: 10.1007/s10528-009-9258-y.

INPI. The International Names Plant Index. Campos dos Goytacazes, 07 de abr. 2007. Available from: <http:// www.inpi.org>. On line. Accessed: 07 de abr. 2010.

LACERDA, D.R. et al. Molecular differentiation of two vicariant neotropical tree species, Plathymenia foliosa and P. reticulate (Mimosoidae), inferred using RAPD markers. Plant Systematics and Evolution, v.235, p.67-77, 2002. Available from: <http:// dx.doi.org/10.1007/s00606-002-0227-8>. Accessed: Jan. 23, 2011. doi: $10.1007 / \mathrm{s} 00606-002-0227-8$.

LEAL, A.A. et al. Efficiency of RAPD versus SSR markers in determination of genetic diversity among popcorn lines. Genetics and Molecular Research, v.9, p.9-18, 2010. Available from: <http://dx.doi.org/10.4238/vol9-1gmr692>. Accessed: Jan. 23, 2011. doi: 10.4238/vol9-1 gmr692.

LYNCH, M.; MILLIGAN, B.G. Analysis of population genetic structure with RAPD markers. Molecular Ecology, v.3, p.91-
99, 1994. Available from: <http://dx.doi.org/10.1111/j.1365294X.1994.tb00109.x>. Accessed: Jan. 22, 2011. doi: 10.1111/ j.1365-294X.1994.tb00109.x.

OLIVEIRA, D.A. et al. Variabilidade genética de populações de favad'anta (Dimorphandra mollis) da região norte do Estado de Minas Gerais. Revista Árvore, v.32, p.355-363, 2008. Available from: <http://www.scielo.br/scielo.php?script=sci_arttext\&pid=S010067622008000200018\&lng=en\&nrm=iso>. Accessed: Fev. 24, 2011. doi: 10.1590/S0100-67622008000200018.

PAMIDIAMARRI, D.V.N.S. et al. Comparative study of interspecific genetic divergence and phylogenic analysis of genus Jatropha by RAPD and AFLP. Molecular Biology Reports, v.32, p.901-907, 2009. Available from: <http://dx.doi.org/ 10.1007/s11033-008-9261-0>. Accessed: Fev. 24, 2011. doi: $10.1007 / \mathrm{s} 11033-008-9261-0$

PERRIER, X. et al. Data analysis methods. In: HAMON, P. et al. Genetic diversity of cultivated tropical plants. Montpellier: CIRAD/Science, 2003. p.43-76.

RAMOS, K. Um mercado com grande potencial no Brasil. Revista Especial Fitoterápico, v.211, p.12-14, 2010.

SAITOU, N.; NEI, M. The neighbor-joining method: a new method for reconstructing phylogenetic trees. Molecular Biology and Evolution, v.4, p.406-425, 1987.

SCHLÖTTERER, C. The evolution of molecular markers just a matter of fashion?. Nature Reviews Genetics, v.5, p.63-69, 2004. Available from: <http://dx.doi.org/10.1038/ nrg1249>. Accessed: Jan. 25, 2011. doi:10.1038/nrg1249.

SCHULMAN, A.H. Molecular markers to assess genetic diversity. Euphytica, v.158, p.313-321, 2007. Available from: <http://dx.doi.org/10.1007/s10681-006-9282-5>. Accessed: Jan. 26, 2011. doi:10.1007/s10681-006-9282-5.

SOUZA, G.A.; MARTINS, E.R. Análise de risco de erosão genética de populações de fava-d'anta (Dimorphandra mollis Benth.) no Norte de Minas Gerais. Revista Brasileira de Plantas Medicinais, v.6, p.42-47, 2004.

SOUZA, H.A.V. et al. Estrutura genética espacial do faveiro de Wilson (Dimorphandra wilsonii - Leguminosae), espécie criticamente ameaçada de extinção, e estratégias para sua conservação e manejo. In: CONGRESSO BRASILEIRO DE GENÉTICA, 55., 2009, Águas de Lindóia, SP. Anais... Águas de Lindóia: Sociedade Brasileira de Genética, 2009. 247p. p.210. 